\title{
HIBRIDITAS NEW MEDIA KOMUNIKASI DAN HOMOGENISASI BUDAYA
}

\author{
Yuliana Rakhmawati \\ Program Studi Ilmu Komunikasi Universitas Trunojoyo Madura \\ Jl.Raya Kamal-Telang PO.BOX 2 Bangkalan 69162 \\ yuliana.rakhmawati@yahoo.com
}

\begin{abstract}
ABSTRAK
Artikel ini mengulas tentang hibriditas komunikasi media baru dan homegenisasi budaya sebagai dampak dari globalisasi. Penulis memandang bahwa peleburan dimensi ruang dan waktu pada sebagian entitas pada era globalisasi mendorong lahirnya standar yang diakui secara paradigmatik dalam pergaulan internasional. Konsekuensi dari konsensus tersebut adalah komodifikasi mempunyai kemampuan dilakukan pada semua pasar, baik pasar barang maupun jasa. Penikmat media merupakan salah satu entitas yang menjadi target untuk penempatan produk-produk tersebut. Proksimitas baik budaya, ideologi dan afiliasi menjadi tema yang diusung dan ditawarkan oleh pasar global. Untuk menjadi bagian dari kampung global (global village) maka segenap penonton diminta untuk berpartisipasi menjadi konsumen media dengan mengikuti setting agenda media. Hibriditas atau pelenturan akan sekat-sekat dalam dimensi ruang, budaya dengan asumsi semacam ambivalensi dan mimikri tidak dapat dihindari lagi. Lahirnya budaya baru yang relative homogen pun menjadi salah satu konsekuensi.
\end{abstract}

Kata kunci: globalisasi, hibriditas, homogenisasi.

\begin{abstract}
This article covers about new media communication hybridity and homogenization as the impact of globalization. Its argues that smelting dimensions of space and time on the part of entities in the era of globalization led to the birth of paradigmatic recognized standards in the international relationship. The consequence of that consensus is the commodification has the ability to be done in all markets, even goods and the services one. One entity that is being targeted for the placement of these products is media connoisseurs. Proximity in cultures, ideologies and affiliations become mainstream theme that was being offered by the global market. To be a part of the global village then the whole audience was asked to participate in media consumption by following the media's agenda setting. Hybridity or the barriers flexing in the dimensions of space and cultural led such assumptions as ambivalence and mimicry can not be avoided anymore. And please welcome the cultural homogenization.
\end{abstract}

Keywords: globalization, hybridity, homogenization

\section{PENDAHULUAN}

Pengarustamaan standar dunia bukan hanya terjadi dalam ranah ekonomi, melainkan memberi dampak pada pengaruh kontestasi geopolitik, sosial dan budaya. Era poskolonial yang ditandai dengan dialog antara dua kubu besar aliran yaitu Marxisme dan postrukturalis semakin menunjukkan dialektika afiliasi. Aliran marxisme berkontribusi dalam kajian 
sejarah imperative materialisme tentang bagaimana komoditas diproduksi, disebarkan dan dikonsumsi. Sedangkan postrukturalis menginferensi era baru yaitu posmodernisme.

Istilah posmodernisme merupakan konsep payung yang menaungi beberapa pilar dan dimensi yang lebih rumit untuk dijelaskan. Bose (1996 menuliskan bahwa posmodernisme lebih berkenaan dengan tematema "baru" seperti representasi, konsumsi, subjektifitas individual dan wacana Aliran ini ditengarai sebagai salah satu pemicu lahirnya globalisasi. Dalam era globalisasi kekuatan imperialisme kapitalis menjadi sebuah sistem ekonomi tunggal sebagai akibat dari kolonialisme dan memicu terjadinya migrasi atau perpindahan manusia yang memberi kontribusi pada keragaman budaya daerah metropolis dan daerah penopang (peripherial).

Masyarkat berkembang dalam bentuk metropolis, dimana terjadi perubahan atas beberapa komponen kehidupan seperti pertukaran, kepemilikan, solidaritas, kebebasan individu, kebudayaan dan kepribadian. Semua itu merupakan bagian dari tradisi universal, dimana salah satu cirinya adalah ketidakmampuan individu melakukan represi ketika terjadi tuntutan kebudayaan objektif. Simmel (2005) menyampaikan bahwa manusia tidak lagi memiliki kualitas individu pada umumnya melainkan tumbuh menjadi keunikan kualitatif yang mempunyai standar subjektif. Hanya saja dalam konteks "filosofi uang", Simmel menambahkan bahwa individu akan menuju masyarakat metropolis dimana memang merupakan tempat yang disediakan untuk konflik.

Scott (1997) mempertanyakan bahwa pada dasarnya globalisasi merupakan sebuah proses sosial atau merupakan retorika politik. Proses sosial dapat terjadi dalam natural setting (kondisi alamiahnya) karena perubahan demografi dan ekologi. Sedangkan dalam perspektif retorika politik, sebagaimana dimensi "art" dalam retorika teradapat konstruksi secara sengaja atas naskah besar dalam hal ini adalah globalisasi. Alvater (1997:323) menunjukkan bahwa globalisasi pada hakekatnya merupakan perpaduan "pasar" dunia yang kompleks seperti digambarkan dalam matrik berikut:

Sumber: Alvater (1997)

\begin{tabular}{|l|l|l|l|}
\hline & \multicolumn{1}{|c|}{ Actor } & \multicolumn{1}{c|}{ Process } & \multicolumn{1}{c|}{ Coordination } \\
\hline Actor & $\begin{array}{l}1.1 \\
\text { Decentred individual; } \\
\text { 'methodological individualism'; } \\
\text { interdependency and } \\
\text { interference }\end{array}$ & $\begin{array}{l}1.2 \\
\text { No knowledge of } \\
\text { the market system's } \\
\text { consequences for action }\end{array}$ & $\begin{array}{l}1.3 \\
\text { Spontaneous non-anticipated } \\
\text { consequences for action'behind } \\
\text { the back of the actor' }\end{array}$ \\
\hline Process & $\begin{array}{l}2.1 \\
\text { Actors as reactors (price } \\
\text { takers), if all are price takers } \\
\text { who determines price? }\end{array}$ & $\begin{array}{l}2.2 \\
\text { Market interference, } \\
\text { market hierarchies, labour } \\
\text { market dependent upon } \\
\text { goods and finance market }\end{array}$ & $\begin{array}{l}\text { Result: balance and } \\
\text { optimization. How are they } \\
\text { come together in the conditions } \\
\text { of the market process? }\end{array}$ \\
\hline Coordination & $\begin{array}{l}3.1 \\
\text { Rules of the game: external } \\
\text { restrictions; property rights; } \\
\text { 'Sachzwang' }\end{array}$ & $\begin{array}{l}3.2 \\
\text { Alternative type of market } \\
\text { processes: from full } \\
\text { competition to monopoly }\end{array}$ & $\begin{array}{l}3.3 \\
\text { Total balance in the system is } \\
\text { impossible }\end{array}$ \\
\hline
\end{tabular}




\begin{tabular}{|l|l|l|l|}
\hline $\begin{array}{l}\text { Observer; } \\
\text { economist }\end{array}$ & $\begin{array}{l}4.1 \\
\text { Actors are like marionettes in } \\
\text { a game directed by observer; } \\
\text { model building }\end{array}$ & $\begin{array}{l}4.2 \\
\text { the observer knows the } \\
\text { logic of the market. He/she } \\
\text { acts like an auctioneer }\end{array}$ & $\begin{array}{l}4.3 \\
\text { Result of the process under } \\
\text { conditions of competition } \\
\text { comparable to those } \\
\text { of planned economies; } \\
\text { perfect competition=prefect } \\
\text { computation' }\end{array}$ \\
\hline $\begin{array}{l}\text { The market's } \\
\text { environment }\end{array}$ & $\begin{array}{l}5.1 \\
\text { Actors use and influence } \\
\text { the social and natural } \\
\text { environment. Thereby } \\
\text { emerges nonmarket-like } \\
\text { interference; extrenalities; } \\
\text { extra-contractual elements on } \\
\text { contractual relations }\end{array}$ & $\begin{array}{l}5.2 \\
\text { Incomplete information } \\
\text { and erroneously } \\
\text { introduced processes; } \\
\text { short-sightedness; market } \\
\text { failure }\end{array}$ & $\begin{array}{l}5.3 \\
\text { The materialism of coordination; } \\
\text { the energy side of the } \\
\text { information flow }\end{array}$ \\
\hline
\end{tabular}

Gambar 1. Kompleksitas Pasar (Market)

Para pelaku pasar (actor) dalam beberapa kuadran selalu bersinggungan dengan proses, koordinasi, pendapat dan pembangunan model yang dilakukan oleh para peneliti serta lingkungan dari pasar itu sendiri. Kuadran diatas menunjukkan bahwa sebagai pelaku pasar berada pada kawasan yang terbentang dari wilayah "bebas" sampai pada wilayah yang sangat kompleks. Menurut penulis, kompleksitas tersebut terbentuk karena kondisi kontestasi pada ranah pergaulan global, dimana setiap negara dalam konteks makro saling mempengaruhi dan memberi dampak pada mekanisme mikro masyarakatnya. Salah satu hal yang dapat ditengarai sebagai pendorong lahirnya pergeseran pola pasar adalah dengan kehadiran era media baru (new media).

Istilah "kapitalisme cetak" dari Benedict Anderson, menurut Appadurai (1949) dapat digunakan untuk melukiskan adanya pelepasan daya baru di pasar dunia. Transaksi yang terjadi antara kekuatan media literacy dan produsen proyek afinitas etnisitas yang menawarkan kebebasan konsumsi media sebagai subtitusi atas komunikasi tatap muka atau komunikasi antarindividu dan kelompok. Semua tema dapat dijadikan komoditas dalam era tersebut, termasuk didalamnya adalah budaya lokalitas dan pembangunan paradox primordialisme. Meskipun dalam perspektif yang lain dialektika nasionalisme juga menjadi tema yang sering diangkat.

Diskusi dan wacana yang berkembang pada era dunia baru yang sering diidentikkan dengan menjelangnya globalisasi adalah kompetisi global dan budaya global. Street (1997) menuliskan bahwa budaya popular seringkali digunakan sebagai tanda dari globalisasi. Ikon budaya popular seperti yang diteliti oleh Ithiel de Sola Pool (1983) hadir karena perkembangan teknologi informasi dan komunikasi. Rakhmawati (2004) dalam riset tentang budaya popular menemukan bahwa kehadiran rezim baru budaya tersebut hadir dalam beragam bentuk mulai dari musik seperti The Police atau U2 yang sangat dikenal di Indonesia dan negara Asia, film Jurassic Park yang menjadi box office di Tokyo sampai moda transportasi dan cara hidup (life style).

\section{Budaya Populer sebagai Komoditas}

Budaya populer lahir seiring dengan masuknya era globalisasi dengan tekologi media baru. Bhabha (1994) dalam "Location of the culture" melihat fenomena ini dalam perspektifposkolonial.Budaya pada hakekatnya merupakan bentuk dialog antara stereotype, 
diskriminasi dan wacana kolonialisme. Ginsburg (2010) menunjukkan bahwa konsepsi Bhaha tentang masyarakat poskolonial adalah ditandai dengan dua modalitas yaitu fetishism dan hybridity. Young (2004) melihat terjadi ambivalensi dari konsep yang ditawarkan oleh Bhaba atas wacana kolonialisme.

Budaya popular yang identik dengan budaya massa selama ini dilekatkan pada kontribusi Amerika. Dengan wacana yang menyertai bahwa kehadiran proksimitas budaya ini menjadi semacam apokaptik dan ancaman bagi masyarakat quo moderen. Dalam konteks Indonesia, budaya popular hampir sering bersinggungan dengan nilainilai dan solidaritas organis dari masyarakat timur. Tayangan yang ditampilakn oleh program produksi industry budaya popular Amerika ditengarai menjadi salah satu pemicu lahirnya sentiment-sentimen negatif dalam bentuk stereotipe, apatisme politik, rasisme dan kekerasan (Winter, 2003).

Tomlison (2003) menunjukkan bahwa kita dapat melihat fenomena tersebut dalam konteks hubungan antara institusi modern dan teknologi dalam rangka meningkatkan konektivitas dan menciptakan gaya budaya, imajinasi, sensibilitas, praktek-praktek dan nilai-nilai. Budaya popular hadir dalam bentuk ikon-ikon, indeks dan simbol. Ikon seperti dalam tampilan iklaniklan (Earth Shoes, Ebony, Eco terrorism dan sebagainya), tayangan televisi dan film layar lebar (Clint Easwood, Ian Fleming), novel (Fitzgerald, F. Scott) dan music (Pendergast, 2000).

Stuart Hall (1980) menggambarkan kehadiran budaya populer yang tepat untuk menggambarkan globalisasi hadir sebagai struktur yang bersamaan global dan lokal. Arus global tanda-tanda, informasi dan gambar tidak menghasilkan budaya standar. Yang baru budaya, yang Aula menyebut era postmodern global, tidak berbicara satu bahasa dan tidak dibentuk oleh satu ideologi dominan, melainkan ditentukan oleh perbedaan dan pluralitas. Hall menambahkan bahwa anggapan atas komersialisasi global hendaknya digeser menjadi wacana homogensisasi sebagai sebuah transaksi mutualisme antara perbedaan. Bahkan yang paling canggih wacana budaya kritis yang paling kompleks tentang ide-ide atas hibriditas atau transbudaya dengan membuat dan melekatkan pemetaan pada keangsaan tertentugagal dalam membuat pemecahan atas teritori budaya, pembatasan, arus lintas batas, fusi dan sebagainya. Dalam koteks ini globalisasi membawa misi deterotialisasi (Tomlison, 2003).

Dalam era budaya popular, semua hal yang dapat memmpunyai nilai tukar makan dapat menjadi komoditas. Sebagai contoh dalam perspektif periklanan, semua lini yang terkait dengan iklan (klien, industri kreatif, pesan, media) memberikan kontribusi dalam penjulana komoditas. Memahami produk budaya popular dalam bentuk iklan, sebenarnya kita perlu bertanya secara kritis apa yang ada dibalik wacana ketika sebuah iklan ditayangkan atau didistribusikan. Iklan pada dasarnya merupakan pesan yang secara sengaja didistribusikan untuk tujuan tertentu. Tetapi dalam konteks budaya popular sebuah pesan sebenarnya bukan hanya mengandung pesanpesan persuasif melainkan juga membawa pesan laten didalamnya.

Penyebaran komoditas budaya popular yang terjadi secara massif menurut persepsi penulis dapat menuju kepada imperialisme budaya. Secara sadar dan dikondisikan, budaya didistribusikan oleh entitas yang mempunyai klaim sebagai negara maju. Klaim kebenaran universal yang dibawa oleh budaya popular dengan perantaraan industri media dan teknologi komunikasi kepada negara yang 
sudah berkembang (developed) dan negara sedang berkembang (developing) yaitu negara Asia dan Amerika Selatan.

Terminologi imperialisme budaya menurut Tomlinson (1991) tidak memiliki sejarah khusus hanya dilekatkan bersamaan dengan gerakan kritis radikal pada tahun 1960an dan menjadi bagian dari gerakan intelektual pada pertengah abad dua puluh. Dalam konteks ini imperialism budaya ditempatkan secara bersamaan dengan ka-jian tentang kapitalisme. Sebenarnya apa yang menjadi "budaya" dalam kapitalisme?. Lebih lanjut menurut Tomlison (1991), imperialisme budaya tidak dapat dipahami secara mutlak dalam terminology 'imperia-lisme media', dalam hal ini identitas budaya bukan semata-mata menunjukkan hubungan sinkronis-spasial tentang dominasi negara melainkan membutuhkan pemahaman le-bih lanjut akan dua cabang kajian yaitu proses sejarah dari perubahan budaya dan secara khusus atas proses modernitas dalam budaya tersebut. Dalam perkembangan era modernitas, budaya dianggap sebagai takdir (Tomlison, 1991: 146).

Potret terjadinya imperialisme budaya menunjukkan terjadi mekanisme sub-ordinasi dalam masyarakat atas budaya. Satu budaya dapat mendominasi budaya yang lain atau bahkan satu budaya memiliki sub-sub budaya yang beragam termasuk didalamnya kehadiran budaya populer. Dalam perspektif penulis budaya populer dapat difahami sebagai budaya yang lahir sebagai bentuk "anti status quo" atas bu-daya mainstream sekaligus dalam konteks makro dapat ditempatkan sebagai bentuk homogenisasi yang diciptakan oleh pasar. Dalam mekanisme pasar, maka budaya popular menjadi komoditas yang melahirkan kebutuhan-kebutuhan dan segala atribut yang melekat.

Dalam kajian budaya (cultural studies) secara umum memahami budaya popular sebagai tempat dimana terjadi konsensuskonsensus relasi kuasa (power) dengan konsep ideologi dan hegemoni (Baker, 2005:9). Dalam kaitannya dengan kekuasaan, budaya popular pada akhirnya dijadikan "alat" untuk mendapatkan, melanggengkan atau menutup kekuasaan lainnya. Budaya popular dengan ciri yang khas seperti: tema yang sederhana, diproduksi secara massal serta beragam entitas mempunyai kesempatan yang sama untuk mengaksesnya maka, posisi strategis budaya popular dalam memobilisasi konsensus relatif dapat diandalkan. Budaya popular menjelma menjadi komoditas merek (brand) yang didistribusikan secara lintas batas dan lintas budaya. Ikon-ikon budaya popular dapat ditemui lewat tayangan serial televisi transnasional, lagu-lagu Billboard atau produk-produk fashion yang dapat ditemui di semua regional.

\section{Homogenisasi Era Posmodernisme}

Dunia telah memiliki mekanisme tersendiri dalam proses interaksi yang khas selama berabad-abad. Pada masa sekarang ini tuntutan atas interaksi tersebut berkembang baik dalam bentuk dan instensitas. Restorasi Meiji merupakan salah satu contoh dibatasinya mekanisme transaksi budaya diantara kelompok-kelompok sosial pada kurun waktu sebelum era ini (Appadurai, 1949: 27). Meskipun dijelaskan oleh Appadurai bahwa interaksi dalam sisi lain sebenarnya tetap terjadi di hampir seluruh belahan dunia salah satunya adalah transaksi ekonomi. Para pedagang menjadi aktor dalam proses perjalanan komoditas dan menjadi pelaku utama dalam perdagangan tersebut.

Tomlison (2003) memiliki pandangan radikal tentang bagaimana implikasi budaya dari globalisasi akan dipikirkan dan dibicarakan. 
Asumsi Tomlison, bahwa wacana tersebut dengan sengaja dikembangkan dengan lebih kompleks dalam pernyataan bahwa globalisasi budaya akan terjadi dalam bentuk penyebaran praktik budaya, kebiasaan, nilai-nilai, produk, pengalaman, cara hidup dari daerah dominan tertentu ke daerah lainnya. Untuk kemudian pola ini secara umum disebut sebagai konsepsi pengaruh budaya secara geopolitik. Fenomena ini muncul dalam beberapa bentuk dari ide-ide tentang Amerikanisasi atau Westernisasi dengan gagasan utama penyebaran kapitalisme global sebagai bentuk imperialisme budaya.

Budaya pada konteks tertentu dapat dijadikan sebagai solusi atas masalah-masalah sosial. Brim (2010: 31) membuat karakteristik dari budaya dalam beberapa tingkatan:

\section{Abstraction creating symbols}

Budaya manusia ada hanya karena manusia dapat mengabstraksi fenomena. Abstraksi adalah kapasitas untuk membuat simbol-simbol atau gagasan-gagasan umum yang membawa makna tertentu, misalnya daengan bahasa dan notasi matematis. Dengan dua perangkat simbol tersebut, manusia mampu mengklasifikasi pengalaman dan generalisasi dari pengalaman tersebut seperti dalam pemberian nama atas objek tertentu prinsip-prinsip dari bahasan dan matematika kita gunakan.

\section{Cooperation creating norms and values}

Kemampuan untuk bekerja sama adalah faktor kedua yang memungkinkan kebudayaan manusia ada. Kerja sama melibatkan menciptakan kehidupan sosial yang kompleks dengan pemba-ngunan norma, atau cara-cara yang berlaku umum untuk melakukan hal-hal tertentu, dan nilai-nilai, atau ide-ide tentang apa yang benar dan salah, baik dan buruk.

\section{Production creating material and non}

\section{material culture}

Budaya dapat tetap bertahan karena keterlibatan manusia dalam proses produksi. Manusia mampu memilih dan menggunakan segenap teknik dan alat dalam usaha meningkatkan nilai dari apa yang diambil dari alam. Alat dan teknik tersebut dikenal sebagai budaya material karena secara empiris dapat diperlihatkan nyata (tangible). Sebaliknya, simbol, norma-norma, nilai-nilai, dan unsur-unsur lain dari budaya nonmaterial dalam bentuk abstraksi (intangible) .

Homogenisasi hadir bukan selalu dalam bentuk yang identik melainkan juga berupa pembuatan standar-standar internasional akan kualitas produk, norma-norma, nilai, ham, pedidikan, hokum dan sebagainya. Akuisisi atas standar tersebut seringkali dengan membawa warna lokalitas. Homogenisasi ini bukan hanya merupakan klaim sepihak dari investorinvestor Amerika atau Eropa, melainkan "hak" dari kapitalis untuk berperan serta aktif dalam distribusi standar budaya internasional termasuk didalamnya adalah investor Indonesia. Lembaga-lembaga internasional baik yang berada dibawah naungan lembaga dunia seperti UN maupun lembaga nirlaba (NGO) mengakui secara paradigmatik kebenaran dari standar-standar yang berlaku secara internasional.

Perubahan ekologi dengan berakhir-nya kebudayaan agraris mempengaruhi perubahan sisi demografi masyarakat. Manusia yang dulu hidup dalam lingkungan agraris yang menganut gemeinschaft termo-bilisasi untuk hadir dalam ruang-ruang urban individualis (geselscaft). Kuasa ekonomi yang selama kebudayaan agraris dimiliki dan dikelola oleh perform-perfom kemudian beralih menjadi konsumsi individu atas produk dan jasa. 


\section{Hibriditas: Korporasi Transkultural}

Pada studi paskakolonial, hibriditas sering dihubungkan dengan konsep kunci dalam kritik budaya yaitu diskusi tentang kontestasi kebudayaan dan relasinya dengan konsep batas dan bentuk ideal dari kosmopolitan. Fenomena yang disebut sebagai hibriditas mengahasilkan beragam variasi tanggapan. Dalam salah satu konsep ditunjukkan bahwa budaya berkembang secara eksklusif dalam bentuk sinkritisme kebudayaan dengan memberi asumsi bahwa hubungan simbiosis yang terjadi menafikan ketidaksetaraan ekonomi, politik dan sosial. Interaksi hibriditas dalam industri musik juga berkembang dengan produktif (Avtar, 2000)

Hibriditas juga dicerminkan pada pencitraan simbol-simbol yang dilekatkan atas sosok feminism. Beberapa penelitian tentang kontribusi hibriditas dalam membentuk citra wanita pada konteks konsumsi budaya internasional. Sejarah dan perubahan "wajah" wanita antar dekade menunjukkan terjadi pergeseran konstruksi atas nilai dan simbol-simbol tertentu. Diskusi ten-tang potret modernitas wanita dengan hubungannya dengan budaya ibu dan literatur sastra berkembang dari berbagai regional. Bohata (2004) menulis tentang konstruksi wanita kelas menengah dalam konteks Welsh (Wales, sebuah Negara bagian dari Britania Raya). Sellei (2004) melakukan penelitian tentang karya puisi sastrawan Hungaria; Brake (2004) memaparkan tentang potret perempuan terdidik pada abad sembilan belas di Inggris; Le Jeune (2004) mengkaji wanita modern menurut versi media harian setempat di Vancouver. Sebagian potret wanita modern dan pencitraan yang melekat dari berbagai negara juga dikaji oleh beberapa peneliti seperti: Ryan (2004); Lavalius (2004); Sharp (2004); Fawcett (2004); Kohler (2004), Robbins (2004); Ascady (2004); Kazue (2004); Bergman (2004), Richardson (2004).
Salah satu ciri negara yang sudah memasuki era pergaulan dunia adalah adanya industri-industri transnasional. Indonesia dan negara lain di Asia sudah menjelang Masyarakat Ekonomi Asia (MEA), artinya bahwa standar yang berlaku pada "pasar" sepenuhnya mengikuti standar selayaknya pasar dimana persaingan merupakan salah satu bentuk kompetisi untuk melihat aktor yang mempunyai kapasitas untuk bertahan. Komoditas yang dipertukarkan dalam masyarakat pasar akan sangat beragam termasuk didalamnya adalah budaya. Bagan berikut memberikan ilustrasi tentang pasar domestik dan posisinya dalam pasar dunia.

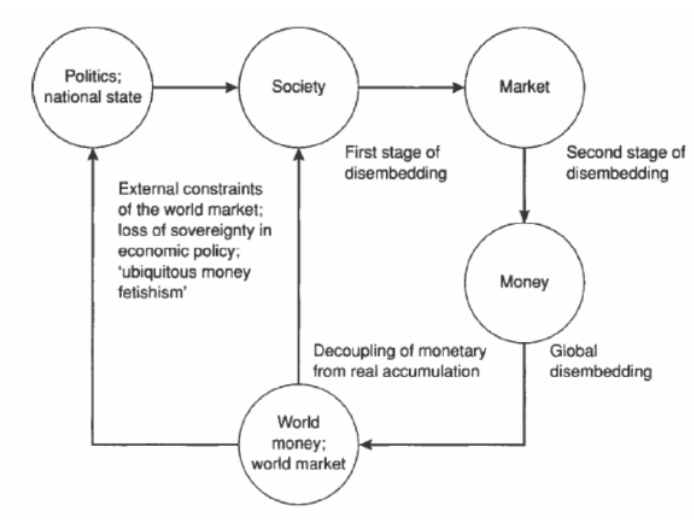

Sumber: Alvater (1997: 319) dalam Scott (1997)

Gambar 2.

Pasar Dunia dan kebijakan ekonomi negara

Kondisi industri budaya dalam sebuah negara termasuk Indonesia didalamnya berada pada sebuah sistem besar dimana terdapat sub-sub jaringan lain yang mempengaruhinya diantaranya: politik suatu negara, atribut penduduknya serta kontribusi pasar dunia. Keterlibatan pasar dunia dalam membentuk pola standarisasi atas komoditas semakin diterima. Beragam produk dari negara-negara berlomba untuk mendapatkan pengakuan standar akan kualifikasinya melalui ISO, IEEE, TIA, EIA atau standar internasional lainnya. Hadirnya standar-standar atas produk 
termasuk budaya menyebabkan terjadinya batas yang semu antar komoditas. Peleburan dan semakin kaburnya batas atara standar domestik dan tuntutan dalam pasar dunia membuat homogenisasi dalam format produk. Dalam konteks tertentu peleburan tersebut bahkan meninggalkan sebuah fenomena yang mengarah pada bentuk hibriditas.

Hibriditas pada sebagian kelompok etnisitas sekaligus ditempatkan sebagai konstruksi atas kelas sosial diberbagai belahan dunia. Di Cina potret hibriditas budaya ini sudah ditemukan sekitar tiga abad sebelum masehi. Budaya materialism yang berkembang pada era poskolonial tersebut membawa atmosfer pertukaran budaya antara Negara Cina (sebagai penduduk pribumi) dengan kelompok pastoral (sebagai entitas kolonial) sangat kental, salah satunya adalah dengan ornament dan arsitektur kuburan golongan elit Cina (Wu, 2013). Dalam perspektif modernitas potret hibriditas Cina juga terjadi dalam bentuk perubahan selera kota: metropolis, inland cities dan tourist cities (Liu, 2012).

Dalam konsep Homi Bhabha tawarkan bahwa hibriditas adalah kamuflase, provo-katif, bid'ah dan kategori disruptif yang terjadi sebagai kebaruan yang memasuki dunia (Bhabha, 1994: 193). Peleburan beberapa nilai budaya dalam format budaya baru bukan hanya terjadi karena pengaruh globalisasi. Perpindahan (migrasi) manusia secara geografis pada kondisi tertentu melahirkan afiliasi pada peleburan budaya. Karla (2005) menuliskan bahwa koordinat migrasi dan penyebaran manusia (diaspora) sebagai negosiasi identitas diantara migrant dengan afiliasi budaya pada daerah asal atau berubah dan menyesuaikan dalam terminologi tuan rumah dan tamu. Dalam konteks Indonesia, etnisitas perantau seperti Madura, Padang, Bugis, Jawa hibriditas sebagai politik identitas juga dilakukan (Rakhmawati, 2015).
Pada abad kesembilan belas, hibri-ditas adalah masalah utama bagi debat budaya (Young: 1995). Pandangan dominan pada saat itu waktu adalah bahwa gagasan manusia menjadi spesies yang berbeda, dan karena itu dari asal yang berbeda, bertentangan dengan penjelasan kitab suci. Selain itu, terjadi tekanan kampanye anti-perbudakan yang menjadikan penekanan bahwa pada hakikatnya manusia adalah satu keluarga. Hibriditas dalam analogi Young adalah seperti persilangan antara dua spesies pada kuda jantan dan keledai betina atau sebaliknya yang disebut hinny. Dalam konteks ini hibdiritas dilakukan untuk menjaga kelangsungan hidup hewan dari bahaya infeilitas dan kepunahan dari generasi ke generasi.

Dalam perskpektif transkultural, hibriditas merupakan kedekatan (proksimiti) yang dikonstruksikan. Budaya ditransformasikan salah satunya dengan menggunakan perkembangan teknologi komunikasi. Kajian dari Tan dkk (2003) atas televisi internasional (konteks Amerika dan Rusia) mendapatkan temuan bahwa televisi masih memiliki pengaruh sebagai sumber realitas sosial, persepsi dan sebagai pemancar budaya. Di Amerika dan semakin banyak negara-negara asing, televisi merupakan sumber utama informasi dan hiburan.

Beberapa teori masih relevan dalam menjelaskan fenomena pengaruh televisi pada budaya dan realitas sosial pemirsa diantaranya: teori kultivasi, teori fungsional kognitif dan teori kognisi sosial. Dengan teori-teori tersebut dibuktikan bahwa persepsi penonton akan televisi sebenarnya merupakan harapan penonton akan realitas ssosial yang sudah disajikan dalam bentuk ringkasan dan penggambaran sederhana akan solusi masalah sosial dari kelompok dan lingkungan mereka. 


\section{KESIMPULAN}

Dalam kaidah komunikasi, minimal mempersyaratkan dua hal yaitu terdapat fungsi komunikator dan komunikan. Dalam dimensi yang lebih luas, komunikasi memerlukan peserta, pesan dan media. Pergerakan dan perkembangan dimensi dan/atau antar dimensi pun kemudian mempersyatakan jenis komunikasi: linier, interaksional maupun transaksional. Dari ketiga kaidah komunikasi tersebut konteks memegang peranan yang penting untuk terjadinya komunikasi yang efektif.

Apabila ditarik dengan bergulirnya wacana poskolonialisme dan posmodernisme maka konteks juga menjadikan dinamika konsekuensi hadirnya dua terminologi tersebut beragam. Menurut penulis, globalisasi merupakan dampak dari kesepakatan (konvensi) yang dinegosiasikan oleh warga dunia. Kemudian homogenisasi budaya yang berkembang ditengah-tengahnya adalah bentuk budaya "transaksional" antara pre-given budaya yang sudah hadir lebih dulu dalam masyarakat tradisional dan klasik dengan artikulasi sosial yang berkembang disekitarnya.

Homogenisasi dan hibriditas bukan hanya mengambil tempat pada masyarakat Anglo-Saxon, akan tetapi menyebar dan dikonsumsi baik secara materi maupun ideologis oleh belahan dunia lainnya. Tiket konser Justin Timberlake yang sold out di negara-negara Asia, U2 menempati posisi teratas bukan hanya di tangga lagu Billboard tetapi juga di Radio Mustang FM Jakarta bahkan di pelosok daerah Indonesia, kafe sudah menjadi tujuan orang-orang untuk sekedar berbincang-bincang. Artinya gaya hidup juga merupakan bagian dari warna homogenisasi atas meleburnya batas-batas geografis dan budaya.

Sedangkan hibriditas dengan wacana multikultalisme menjadikan warna budaya yang beraneka "diminta" untuk diterima dalam koridor kebijakan politik. Seperti contoh di Indonesia, beragam etnisitas yang mempunyai afiliasi atas budaya tradisionalnya menjadi dan diminta hadir dalam budaya nasional yaitu budaya Indoensia. Peleburan tersebut bukan dalam konteks menempatkan budaya tradisional menjadi sub kultur dari budaya nasional, akan tetapi meminta para afiliator budaya klasik menerima kehadiran warna budaya baru yang melebur dalam simbolsimbol, indeks dan ikon dari ke-Indonesia-an.

Mencoba berada ditengah-tengah dalam konteks era posmodernisme dengan homogenisasi dan hibriditas mungkin adalah pilihan strategis. Seperti penggalan refrain "Accentuate the positive" dari Johnny Mercer yang dikutp oleh Bhabha (1994) dapat menjadi satu wacana baru dalam pembahasan tentang komodifikasi dan homogenisasi. Bahwa you've got to asccentuate the positive, eliminate the negative, latch to the affirmative, don't mess with Mister in between.

\section{DAFTAR PUSTAKA}

Acsady, Judith (2004). 'The Woman Of The Twentieth Century': The Feminist Vision And Its Reception In The Hungarian Press 1904-14 dalam New Woman Hybridities Femininity, feminism and international consumer culture,1880-1930 Ann Heilmann and Margaret Beetham (ed). New York. Routledge. 
Altvater, Elmar; Birgit Mahnkopf. (1997). The World Market Unbound dalam The Limits Of Globalization : Cases And Arguments. Alan Scott (Ed) London. Routledge.

Appadurai, Arjun. 1949. Modernity at Large: Cultural Dimensions of Globalization. Minneapolis. University of Minnesota Press.

Avtar Brah, Annie E. Coombes (ed) (2000). Hybridity and its Discontents Politics, science, culture London. Routledge.

Barker, Chris (2005). Cultural Studies, Theory and Practice. London. Sage.

Bergman, Jill (2004). 'Natural' Divisions/National Divisions: Whiteness And The American New Woman In The General Federation Of Women's Clubs dalam New Woman Hybridities Femininity, feminism and international consumer culture,1880-1930 Ann Heilmann and Margaret Beetham (ed). New York. Routledge.

Bhabha, Homi K (1994). The Location of The Culture. New York. Routledge.

Bose, Purnima. (1996). National Culture and the New Global System?Colonial Desire. Jurnal Victorian Studies. Summer 1996; 39, 4 hal.585

Couteau, Jean. (n/a). Beberapa Catatan Tentang Homogenisasi Budaya didalam Dunia yang Menglobal dari http://kebudayaan.kemdikbud.go.id/wp-content/uploads/sites/46/2013/ 10/jean-couteau warisan-dan-pewarisan budaya penyerbukan-silang-budaya beberapa-catatan-tentanghomogenisasi-budaya-di-dalam-dunia-yang-menglobal.pdf didownload pada 10 Mei 2016.

Fawcett, Hillary (2004). Romance, Glamour And The Exotic: Femininity And Fashion In Britain In The 1900s dalam New Woman Hybridities Femininity, feminism and international consumer culture,1880-1930 Ann Heilmann and Margaret Beetham (ed). New York. Routledge.

Fiske, J. (1989). Understanding popular culture. London: Unwin Hyman.

Giddens, Antoni (1984). The Constitution of Society Outline of the Theory of Structuration. Cambridge. Polity Press.

Ginsburg, S h a i. (2010). Signs and Wonders. Fetishism and Hybridity in Homi Bhabha's The Location of Culture CR: The New Centennial Review, Vol. 9, No. 3, 2010, pp. 229-250, issn 1532-687x. Michigan State University Board of Trustees.

Hall, Stuart (1980) Culture, Media, Language Working Papers in Cultural Studies,1972-79. London Routledge in association with the Centre for Contemporary Cultural Studies University of Birmingham.

Tomlinson, John (1991). Cultural Imperalisme. London. Continuum. 
Kalra Virinder S; Raminder Kaur; John Hutnyk (2005). Diaspora \& Hybridity. London. Sage Publications.

Kazue, Muta (2004). The New Woman In Japan: Radicalism And Ambivalence Towards Love And Sex dalam New Woman Hybridities Femininity, feminism and international consumer culture,1880-1930 Ann Heilmann and Margaret Beetham (ed). New York. Routledge.

Kohler, Angelika (2004). Charged With Ambiguity: The Image Of The New Woman In American Cartoons dalam New Woman Hybridities Femininity, feminism and international consumer culture,1880-1930 Ann Heilmann and Margaret Beetham (ed). New York. Routledge.

Lavallius, Maryanngialanel (2004). Subverting The Flapper: The Unlikely Alliance Of Irish Popular And Ecclesiastical Press In The 1920s dalam New Woman Hybridities Femininity, feminism and international consumer culture,1880-1930 Ann Heilmann and Margaret Beetham (ed). New York. Routledge.

Liu, Xiaoping (2012). Perspective on the problem of the Chinese urban space homogenization and identity creation in the era of globalization dalam Applied Mechanics and Materials Vols. 174-177 (2012) pp 2226-223

Pendergast, Tom Sara Pendergast (2000). St. James Encyclopedia of Popular Culture. St. James Press. Thomson Gale.

Pool, Ithiel de Soola (1983). Technologies of Freedom. Cambridge. The Belknap Press of Harvard University Press.

Rakhmawati, Yuliana (2004). Representasi Ikon-ikon Budaya Populer dalam Film Andai Ia Tahu. UNS. Tesis tidak diterbitkan.

(2015). Diaspora Pilantropi Tukang Cukur Madura. Yogyakarta. Elmatera Publishing.

Richardson, Angelique (2004). The Birth Of National Hygiene And Efficiency: Women And Eugenics In Britain And America 1865-1915 dalam New Woman Hybridities Femininity, feminism and international consumer culture,1880-1930 Ann Heilmann and Margaret Beetham (ed). New York. Routledge.

Robbins, Trina (2004). T R I N A The Day Of The Girl: Nell Brinkley And The New Woman dalam New Woman Hybridities Femininity, feminism and international consumer culture,1880-1930 Ann Heilmann and Margaret Beetham (ed). New York. Routledge.

Ryan, Louise (2004). Locating The Flapper In Rural Irish Society: The Irish Provincial Press And The Modern Woman In The 1920s dalam New Woman Hybridities Femininity, feminism and international consumer culture,1880-1930 Ann Heilmann and Margaret Beetham (ed). New York. Routledge. 
Scott, Alan (ed) (1997).The Limits of Globalization : cases and arguments. London. Routledge.

Sharp, Ingrid (2004). Riding The Tiger: Ambivalent Images Of The New Woman In The Popular Press Of The Weimar Republic dalam New Woman Hybridities Femininity, feminism and international consumer culture,1880-1930 Ann Heilmann and Margaret Beetham (ed). New York. Routledge.

Simmel, Georg (2005). The Philosophy of Money. New York. Routledge.

Street, John (1997). 'Across The Universe' The Limits Of Global Popular Culture dalam The Limits Of Globalization : Cases And Arguments. Alan Scott (Ed). London. Routledge.

Tan, Alexis; Gedean Tan; Todd Gibson (2003). Socialization Effects of America Television on International Audiences dalam The Impact of International Television : A Paradigm Shift, Michael E Elasmen (ed). New Jersey. Lawrence Erlbaum Associates Publishers.

Tomlinson, John (2003) . Culture, Modernity and Immediacy dalam Global America? The Cultural Consequences Of Globalization. Beck Ulrich (ed). Liverpool University Press.

Winter, Rainer (2003). Global Media, Cultural Change and the Transformation of the Local: The Contribution of Cultural Studies to a Sociologyof Hybrid Formations dalam Global America?The Cultural Consequences of Globalization. Ulrich Beck et.al (ed). Liverpool University Press

Wu, Xiaolong. (2013). Cultural hybridity and social status: eite tombs on China's Northern Frontier During The Third BC. Jurnal Arts and Humanities Full Text Mar 2013: 87, 335 hal.121

Young, Robert J.C (1995). Colonial Desire: Hybridity in Theory, Culture and Race.London. Routledge.

--(2004). White Mythologies. New York. Routledge. 